\title{
Survey and analysis of the indicators of intellectual capital in MiPymes of León, Guanajuato under the Intellectus Model approach
}

\section{Análisis de la correlación de indicadores de la gestión del capital intelectual en Mipymes de León, Guanajuato bajo el enfoque del Modelo Intellectus}

\author{
DÍAZ-GONZÁLEZ, Claudia†*, ORDAZ-PICÓN, Carla and GÓMEZ-NEGRETE, Guadalupe de Jesús
}

Tecnológico Nacional de México/Instituto Tecnológico de León

ID $1^{\text {st }}$ Author: Claudia, Díaz-González / ORC ID: 0000-0001-3816-8829, CVU CONACYT ID: 97754

ID $1^{\text {st }}$ Coauthor: Carla, Ordaz-Picón / ORC ID: 0000-0001-8038-0231, CVU CONACYT ID: 874776

ID $2^{\text {nd }}$ Coauthor: Guadalupe de Jesús, Gómez-Negrete / ORC ID: 0000-0003-3526-5618

DOI: $10.35429 / \mathrm{JBAB} .2021 .8 .5 .1 .11$

Received March 18, 2021; Accepted June 30, 2021

\begin{abstract}
This paper presents the result of a correlational study derived from the exploratory analysis of a previous work in 2019 on the behavior of key indicators of intellectual capital management under the approach of socioevolutionary models such as the Intellectus Model from which a 27-question-survey was designed and applied to a sample of 69 companies of different sizes and lines of work in the city of León. The results of the study show that in the companies subjects of the research are found significant positive correlations in the behavior of key indicators such as levels of integration and motivation of staff, promotion mechanisms, level of involvement in decision-making, levels of education, propensity to change or improvement in products and processes, transfer of knowledge in the form of intangible assets as trademarks and patents which allow companies to increase their chances of permanence and growth in the long term. The above gathered from the statistical analysis applied to the database constructed from the results of the field research among the companies that agreed to answer the initial survey.
\end{abstract}

Knowledge Economy, Intellectual Capital, intangible assets, Intellectus Model

\section{Resumen}

Este artículo presenta el resultado de un estudio correlacional derivado del análisis exploratorio de un trabajo previo en 2019 sobre el comportamiento de indicadores clave de la gestión del capital intelectual bajo el enfoque de modelos socioevolutivos como el Modelo Intellectus a partir del cual se La encuesta se diseñó y aplicó a una muestra de 69 empresas de diferentes tamaños y líneas de trabajo en la ciudad de León. Los resultados del estudio muestran que en las empresas objeto de investigación se encuentran correlaciones positivas significativas en el comportamiento de indicadores clave como niveles de integración y motivación del personal, mecanismos de promoción, nivel de implicación en la toma de decisiones, niveles de formación, propensión al cambio o mejora de productos y procesos, transferencia de conocimiento en forma de activos intangibles como marcas y patentes que permitan a las empresas incrementar sus posibilidades de permanencia y crecimiento en el largo plazo. Lo anterior extraído del análisis estadístico aplicado a la base de datos construida a partir de los resultados de la investigación de campo entre las empresas que aceptaron responder la encuesta inicial.

Economía del Conocimiento, Capital Intelectual, Activos intangibles, Modelo Intellectus

Citation: DÍAZ-GONZÁLEZ, Claudia, ORDAZ-PICÓN, Carla and GÓMEZ-NEGRETE, Guadalupe de Jesús. Survey and analysis of the indicators of intellectual capital in MiPymes of León, Guanajuato under the Intellectus Model approach. Journal-Business Administration-Marketing; Accounting. 2021. 5-8: 1-11

\footnotetext{
* Correspondence to Author (e-mail: claudia.diaz@leon.tecnm.mx)

$\dagger$ Researcher contributing as first author
} 
The studies related with the management of intellectual capital are part of a new generation approach within business management that acquired great relevance as part of the emergence of the fourth industrial revolution and the trends of the new styles of leadership and management related to the industries associated with information and communication technologies.

The era of digitization developed widespread rapidly at an international level, as consequence the main companies associated with that industry began to turn their attention to intangible assets as part of their business strategy. Innovation as a key concept along with $R \& D$ in English, also known as I+D were part of the discussion in the public policy agenda at national and regional levels during the first decades of this century. Hence, in the last 15 years, business strategies that increasingly recognize the value of intangible assets through intellectual capital have been developed. In this work, evidence of a positive correlation is shown between the indicators associated with forms of work aimed at participation, creativity and knowledge flow and the propensity to innovate through patenting or intellectual property registration initiatives in the companies, subjects of the investigation, located in the city of León and neighboring cities.

\section{Introduction}

This article presents a correlational analysis of indicators result from the exploratory study proposed by the research group on intellectual capital and innovation in organizations which takes as a starting point, key concepts in the Knowledge Economy and in particular it tries to discuss the relevance of intellectual capital as one of the intangible assets that generate value for innovation in organizations and that show analytical trends to evaluate organizational management styles in local and regional economies. In this regard, there is an extensive literature that has documented the changes in the business management paradigm in terms of the management of human and intellectual capital. In particular, the Intellectus Model proposed by Bueno and Merino in 2008 and updated in 2015, proposes an methodological analysis that sums up 3 dimensions for the study of intellectual capital and that were taken up in this work to organize a survey directed to the personnel of Guanajuato companies.
In this sense, the measurement and analysis of indicators of the intellectual capital of the Intellectus Model is part of the investigation of this phenomenon in which we find some key dimensions that explain some trends in the results of a management oriented to the use of intangible assets. In this way, the results of the exploratory study, started in 2019, allowed the construction of a database which was statistically analyzed to find significant correlations amongst the variables analyzed in addition to prove the hypothesis about the positive relationship between the management styles oriented to motivation and promotion of human talent, and the changes in the generation of products for innovation translated into intellectual property registrations, in particular patents, trademarks, software copyright registrations and utility models for the local and regional industry.

The results obtained yielded significant correlations that are shown in the results section. The conclusions of the work seek to offer data to confirm that the management of intellectual capital (knowledge, innovation, link with the environment) will continue to be key in the administration of organizations as part of their strategic planning to remain in the market.

Today, more than ever, faced with a scenario of uncertainty for decision-making, the work carried out within work teams aimed at managing creativity and innovation become assets of great value to guarantee the survival of companies in microregions such as those that were the subject of the study. Next, some approaches are presented about the frame of reference that guide the assumptions of the analysis work in order to justify the theoretical and methodological relevance of the field work and the contrasting of empirical evidence against trends in the field of business management.

\section{Knowledge management and Intellectual Capital}

The vertiginous evolution of the capitalist industrialization model and its worldwide expansion from the second half of the 20th century gave rise to new paradigms to explain the emergence of new factors of production. In particular, the intervention of technology as a detonator of production and with it a need to establish new schemes of relationship with human capital (formerly known as labor or personnel).

DÍAZ-GONZÁLEZ, Claudia, ORDAZ-PICÓN, Carla and GÓMEZNEGRETE, Guadalupe de Jesús. Survey and analysis of the indicators of intellectual capital in MiPymes of León, Guanajuato under the Intellectus Model approach. Journal-Business Administration-Marketing; Accounting. 2021 
Until then, technological change was considered an exogenous factor to this function. Apparently, the incorporation of innovation and knowledge variables began to better explain why industrialized economies achieved higher growth rates than emerging economies, which, despite investing more in capital, did not show a better performance.

In the last decade of the 20th century, the main literature on Knowledge Management and Intellectual Capital in organizations began its development and with it came the first efforts to evaluate this last concept. The knowledge society, according to Castells (2002), is a society in which the conditions for the generation of knowledge and information processing have been substantially altered by a technological revolution focused on information processing, the generation of knowledge and the information technology

The arrival of the information society and its evolution towards the knowledge society has placed intangible assets as one of the main sources of creating a sustainable competitive advantage for the company. In this context, the concept of Intellectual Capital arises as a strategic perspective of the intangibles of the organization.

According to Edvinsson and Malone (1999), Intellectual Capital refers to the value resulting from the set of intangible assets created by the company. This intangible resource is based whether on knowledge or human intellect and developed in the organization. It therefore includes a set of assets such as organizational systems, brands, databases, patents, customer relations, among others. These assets, as Lev (2001) points out, respond to the process of value creation, innovation, or cognitive base of $R \& D$ of organizational practices and policies or of management of the function of people as possessors of knowledge. Kristandl and Bontis (2007) incorporate other relevant elements into the analysis by pointing out that intellectual capital is defined as "those strategic organizational resources that allow it to create sustainable value, but that are not available to a large number of companies. (shortage). They generate potential future benefits that cannot be taken by others (appropriability) and that are not imitable by competitors or substitutable by other resources. They are not transferable due to their organizational nature.
Under this definition, assets of an intangible nature are combined so they can generate new knowledge and be transformed into business competencies or the creation of competitive advantage.

In recent years, administrators have accepted that the intangible asset is formed by human capital, structural capital, relational capital, leadership, feelings and employee turnover, and knowledge management; and not by the cash, the building or the equipment, which make the most important and critical difference of the organization, besides that ' this can be transformed into financial gains and in support of the innovation capacity of an 'organization (Bontis and Fitz -enz, 2002).

Intellectual capital is part of knowledge management, it resides in the organization because it is the knowledge created by same organization and that creates a sustainable competitive advantage, which it develops to increase business performance (Bontis and Fitzenzy, 2002).

Within the studies carried out on the performance of companies in Latin America, such as the one carried out by Fernández-Jordán and Martos (2013) in Mipymes (Micro, small and medium size companies) in some regions of Brazil, there is empirical evidence that the way of managing human capital can define the company's positioning in the market, increase its competitive advantages derived from investment in training, process certification, improvements in organizational communication and better management of work teams, thus increasing the possibilities for innovation and improvement.

The importance of intellectual capital today is associated with competitive advantage, with the creation of distinctive competencies, and with the creation of technology management and knowledge transfer amongst the individual, the team, and the organization (Chaharbaghi and Cripps, 2006).

Nonaka and Takeuchi (cited by Bontis and Fitz-enzy, 2002) mention that knowledge management includes three primary activities: 1) knowledge generation, which describes the way in which employees improvise and innovate in the organization; 
2) knowledge integration, which describes how employees transform their tacit knowledge into explicit knowledge by encoding their ideas within the organization's systems, and 3) knowledge sharing, which describes the socialization process through which employees share knowledge with others.

Finally, the definition proposed in the studies of Bueno (2008) in which he poses intellectual capital as "accumulation of knowledge that creates value or cognitive wealth owned by an organization, composed of a set of assets of an intangible nature or resources and capacities based on knowledge that when put into action, according to a certain strategy, in combination with physical or tangible capital, is capable of producing goods and services and of generating competitive advantages or essential skills for the organization in the market".

Although the first studies interested in addressing the issue have been carried out in developed countries where companies are listed on the stock market as part of their financial dynamics, and which showed differences between their book value and their market value, it is interesting to observe the behavior of economic agents, particularly small and medium-sized companies in the face of the changes imposed by the economic and commercial dynamics strongly interconnected with the leading industries of the international economy.

Today, concepts, ideas, images - not things - are the real valuable items in the new economy. For this reason, it is essential to observe, and even encourage, that local companies recognize this value and begin to make decisions that introduce processes aimed at taking advantage of the new opportunities that the new context of the international economy represents.

According to Osio Havriluk (2016) "it should be understood that, in the 21 st century, the predominant technological matrices are becoming obsolete, and this has considerable effects on markets and organizational structures. IT has revolutionized organizations and has generated new ways of working that require more specialized and knowledgeable people.
The know-how has become a totally strategic factor in the production process, and one of the most profitable investments in the entire economy. In this new society, capital must focus on the productivity of knowledge and service workers, which constitutes real challenges for the different sectors.

\section{Intellectus Model for Measurement and Management of Human Capital}

As part of the development of the theoretical and methodological approaches around knowledge management, the proposal of Eduardo Bueno and the Intellectus Model (2011) is retaken. Such model, provides a new and adequate tool to measure, inform and strategically systematically and integrally direct the organizational resources based on the knowledge that comprise it.

Within the development of models for the measurement and management of Intellectual Capital in organizations, three main approaches are proposed. The first one called "financial-administrative" with a clear accounting influence; the second "corporate strategic approach" and the third "socialevolutionary approach" that initiates the development of Intellectual Capital for the following years.

The Intellectus Model that is taken as a reference in this work is framed within the socioevolutionary approaches that result from the most evolved models and with concern for more dynamic components or capital such as "social", "cultural", "innovation" or of "entrepreneurship."

The Intellectus Model for the measurement and management of intellectual capital emerged in 2003 having as a precedent the Intellectus Model of the Euroforum Escorial University Institute. Subsequently, and derived from studies and findings in empirical research, an updated version was proposed in 2011 led by Bueno and Merino.

In this way, in 2011 the model that incorporated the elements to do so was proposed: systemic, open, adaptive and flexible and that is observed in Figure 1. 


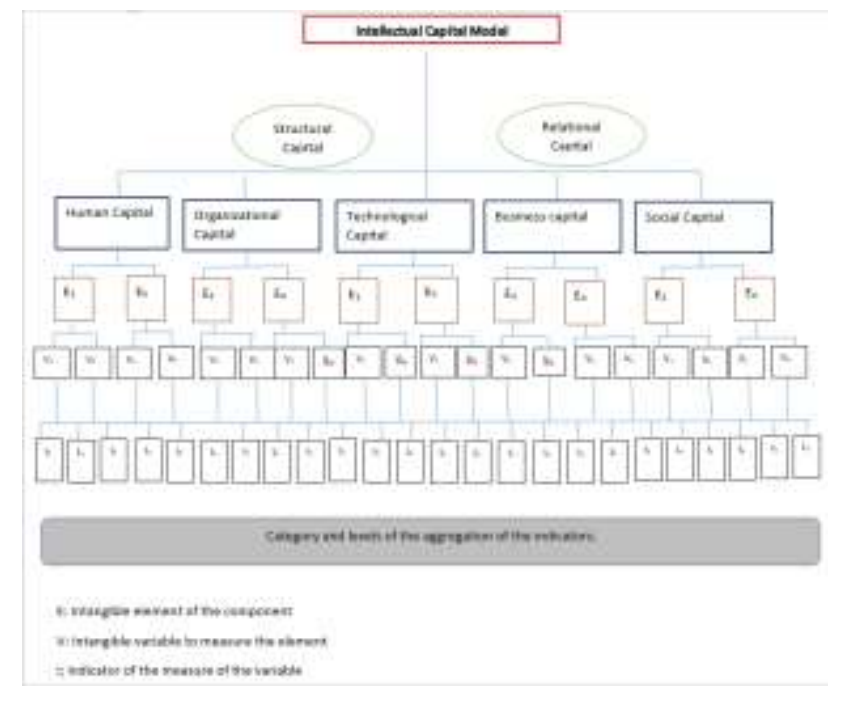

Figure 1 Intelectus model: Basic structure and its components

Source: CIC-IADE (UAM, 2003)

Figure 1 shows the "pertinence tree" analysis technique, which allows observing the elements of a topic in an increasingly detailed way by subdividing topics into smaller and smaller subtopics.

The Intellectus Model aims to provide an orderly framework for reflection on the management of the Intellectual Capital of the organization. Although in principle the model adopted as a starting point companies dedicated to $\mathrm{R} \& \mathrm{D}$, financial institutions, consulting firms, or evolving towards new applications that have shown a degree of adjustment for the private and public sector, as shown by the case studies of Spanish companies in where the proposal of the model was born.

The model distinguishes dimensions of intellectual capital: human capital, structural capital (subdivided into organizational and technological capital) and relational capital (business capital and social capital).

For the Intellectus Model, human capital is defined as those attitudes, skills and abilities that are in line with the challenges and values of the organization. These abilities and skills can be acquired throughout life, either through formal studies or through informal knowledge, which people acquire through experience. In this sense, it is emphasized that many workers increase their productivity by learning new techniques on the job or by perfecting old ones.
Structural capital is made up of two subgroups such as organizational capital and technological capital, the first associated with the structural scope of designs, processes, and culture and the second linked to the effort in $\mathrm{R} \& \mathrm{D}$, the use of technological endowments and the results of $R \& D$.

Social relational capital, in whose framework are the relationships outside the business environment (social commitment, public image, reputation, prestige, social action) In this regard, the study by Martín de Castro and Alama (2009) shows that there is a positive relationship between this type of capital and the innovation of products and services derived from inter-organizational knowledge, from the relationship with clients, suppliers and alliances with competitors in the same industry, moving towards a new vision of innovation based on intellectual capital.

Finally, Entrepreneurship and innovation capital that encompasses efforts to improve or new products of the company whose benefits are perceived in costs, quality, time, and performance, as well as innovations that cause technological and social impact. It also adds the valuable component (Be+ Being), which contemplates the willingness of people to generate the innovations referred to. This last dimension consisted in the identification of accelerating elements of the original capitals of the model, which were integrated to form the latter capital. (See Figure 1)

According to the interpretation of the Intellectus Model, the sum of these dimensions of intellectual capital generates a systemic composition that allows obtaining an overview of the intangible assets that the organization owns, thus generating the necessary information for making decisions with a strategic sense for proper management of knowledge.

The exercise of identification and measurement of Intellectual Capital is an essential requirement to act coherently from the management of assets that add value to organizations due to their relationship, with the capabilities that drive the set of tangible available resources. For the purposes of this work, the Intellectus Model helps us to identify indicators that allow periodic monitoring of the evolution of such assets in organizations. 
This work seeks to validate and improve the measurement instruments under a mixed approach (quantitative and qualitative) different spheres, agents, and contexts. In this case, it was decided to use it as part of the frame of reference for an exploratory and descriptive study on the dynamics observed in the management of intellectual capital within a sample of companies in León, Guanajuato.

According to Bueno, Intellectual Capital allows for an appropriate methodology to generate a key instance for reflection that involves moving from the "creation of a company" to the "development of a business".

\section{Methodology and Results}

In this research, it was taken as a starting point the results of the survey applied in 2019 published in the Journal of Economic Studies (Díaz and Ordaz, 2020). In this work an analysis was carried out using the statistical technique of linear regression.

The linear regression forecast model allows to find the expected value of a random variable $a$ when $b$ takes on a specific value. The application of this method implies an assumption of linearity when the demand presents an increasing or decreasing behavior, for this reason, it is essential that prior to the selection of this method there is a regression analysis that determines the intensity of the relationships between the variables that make up the model.

The simple linear regression forecast is an optimal model for patterns of demand with a trend (increasing or decreasing), that is, patterns that present a linear relationship between demand and time.

The goal of a regression analysis is to determine the relationship between a dependent variable and one or more independent variables. In order to carry out this relationship, a functional relationship between the variables must be postulated.

When it comes to an independent variable, the functional form that is most used in practice is the linear relationship. The regression analysis then determines the intensity between the variables through correlation and determination coefficients.

The following is the straight-line equation formula:

$$
Y=a_{0}+a_{1} X
$$

In this second stage of data analysis that was carried out with the database derived from the 2019 survey, the possible relationships between the results obtained were reviewed; for such purpose, the variables were confronted, in the spirit of seeking answers to the following hypothesis:

There is significant statistical evidence on the positive correlation of the variables of the Intellectus Model associated with the management of human capital and innovation capital in the MIPYMES (Micro, small and medium size companies) of Silao, León and San Francisco del Rincón which were part in the study.

Therefore, a review process was started, to compare the results, so that question by question of the survey was reviewed, first to verify that each variable had been measured and then to identify some type of relationship between the variables.

To obtain the result of whether there was a relationship between each question, comparison matrices were made, and graphs were designed through the result obtained to see how their behavior was and, thus finally establish the correlation analysis. Table 1 shows the operationalization of the questions in the initial questionnaire (Díaz and Ordaz, 2020).

\begin{tabular}{|c|c|c|c|}
\hline Elemento & Variable & Indicator & Question \\
\hline \multirow[t]{2}{*}{$\begin{array}{l}\text { Values and } \\
\text { attitudes }\end{array}$} & Self-motivation & $\begin{array}{l}\text { Number of people who value } \\
\text { positively the working environment }\end{array}$ & \\
\hline & Satisfaction & $\begin{array}{l}\text { Number of people satisfied with the } \\
\text { relaationship colaborator/superior }\end{array}$ & 2 \\
\hline Aptitudes & Experience & $\begin{array}{l}\text { Labor seniority in the working } \\
\text { position }\end{array}$ & 4 \\
\hline $\begin{array}{l}\text { Aptitudes } \\
\text { capabilities }\end{array}$ & $\begin{array}{l}\text { Personal development } \\
\text { and conciliation of } \\
\text { working life }\end{array}$ & $\begin{array}{l}\% \text { of people with family } \\
\text { responsabilities }\end{array}$ & 6 \\
\hline $\begin{array}{ll}\begin{array}{l}\text { Aptitudes } \\
\text { capabilities }\end{array} & y \\
\end{array}$ & Leadership & $\begin{array}{l}\% \text { of people satisfied in their job } \\
\text { positions }\end{array}$ & 3 \\
\hline \multirow[t]{2}{*}{ Capabilities } & \multirow[t]{2}{*}{$\begin{array}{l}\begin{array}{l}\text { Colaboration } \\
\text { (teamwork) }\end{array} \\
\end{array}$} & $\begin{array}{l}\text { Number of people who participate } \\
\text { in two or more teams at work }\end{array}$ & 7 \\
\hline & & $\begin{array}{l}\text { Number of people who participate } \\
\text { in two or more teams at work } \\
\text { outside work }\end{array}$ & 8 \\
\hline Capabilities & $\begin{array}{l}\text { Comunication } \\
\text { (knowledge exchange) }\end{array}$ & $\begin{array}{l}\text { Number of contributions taken at } \\
\text { practice }\end{array}$ & 9 \\
\hline
\end{tabular}

Table 1 Classification of questions by variable Source: Own elaboration based on the MiPymes Survey (Díaz and Ordaz, 2020)

Table 2 shows the result of the analysis and presented in the previous table allows to affirm that there is a possible relationship between the feeling of belonging, selfmotivation, and the variable of patents and utility models, communication (knowledge exchange), proposed by the Intellectus Model.

DÍAZ-GONZÁLEZ, Claudia, ORDAZ-PICÓN, Carla and GÓMEZNEGRETE, Guadalupe de Jesús. Survey and analysis of the indicators of intellectual capital in MiPymes of León, Guanajuato under the Intellectus Model approach. Journal-Business Administration-Marketing; Accounting. 2021 
As well as, sociability and customer orientation, so the following analysis first involved the graphic technique to identify possible correlations, which were identified, so linear correlation models were used to obtain a straight line of best fit, using least squares, basing this analysis on the following models.

\begin{tabular}{|l|c|l|}
\hline \multicolumn{3}{|c|}{ List of questions from the questionnaire to Company / employee } \\
\hline Variable & Question & Relation \\
\hline $\begin{array}{l}\text { Feeling of belonging and commitment and } \\
\text { self-motivation }\end{array}$ & 1 y 3 & Yes \\
\hline $\begin{array}{l}\text { Sociability and customer orientation and Self- } \\
\text { motivation }\end{array}$ & 6 y 1 & Yes \\
\hline Flexibility and adaptability and creativity & 8 y 9 & No \\
\hline
\end{tabular}

Table 2 List of questions from the questionnaire to Companies / employee

Source: Own Elaboration based on data from the Survey of MSMEs (Díaz and Ordaz, 2020)

Regarding the correlation between the variables "Patents and utility models and communication (exchange and knowledge)", using linear regression. Feeling of belonging, commitment and self-motivation, the line of best fit was used from the straight line of least squares regression.

$Y=a_{0}+a_{1} X$

Where:

$\mathrm{Y}=$ Straight line of best fit

$\mathrm{a}_{0}=$ Constant

$\mathrm{a}_{1}=$ Constant

$\mathrm{X}=$ Variable

Same that are obtained from the following normal equations:

$a_{0}=\frac{\left(\sum y\right)\left(\sum x^{2}\right)-\left(\sum x\right)\left(\sum x y\right)}{N\left(\sum x^{2}\right)-\left(\sum x\right)^{2}}$

$a_{1}=\frac{N\left(\sum x y\right)-\left(\sum x^{*} \sum y\right)}{N\left(\sum x^{2}\right)-\left(\sum x\right)^{2}}$

To obtain the values of $\mathrm{a} 0$ and $\mathrm{a} 1$, the following table was made where the values of $x, y, x^{2}, x y, y^{2}$

\begin{tabular}{|r|r|r|r|r|}
$\begin{array}{c}\text { Development of the last } \\
\text { 3 years (X) }\end{array}$ & \multicolumn{1}{c}{$\begin{array}{c}\text { Proposals or } \\
\text { projects (Y) }\end{array}$} & \multicolumn{1}{c|}{ X' } & \multicolumn{1}{c|}{$\mathbf{Y}^{2}$} \\
\hline 76 & 86 & 5776 & 6536 & 7396 \\
\hline 39 & 66 & 1521 & 2574 & 4356 \\
\hline 23 & 51 & 529 & 1173 & 2601 \\
\hline 22 & 42 & 484 & 924 & 1764 \\
\hline 0 & 30 & 0 & 0 & 900 \\
\hline 0 & 12 & 0 & 0 & 144 \\
\hline $\mathbf{1 6 0}$ & $\mathbf{2 8 7}$ & $\mathbf{8 3 1 0}$ & $\mathbf{1 1 2 0 7}$ & $\mathbf{1 7 1 6 1}$ \\
\hline
\end{tabular}

Table 3 Initial values. Variables: feeling of belonging, commitment, and self-motivation

Source. Own elaboration based on data from the MiPymes Survey (Díaz y Ordaz, 2020)
Which allows identifying the best fit equation as:

$\mathrm{Y}=24.3961253+.8788953 \mathrm{X}$

From this equation, it is possible to establish a linear correlation as can be seen in Table 4.

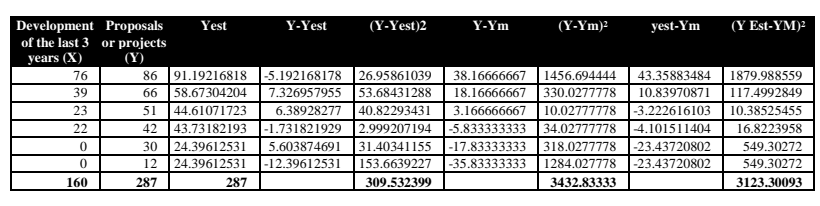

Table 4 Variables correlation: feeling of belonging, commitment and self-motivation

Source: Own Elaboration based on Survey data (Díaz and Ordaz, 2020)

The correlation becomes significant if you observe the behavior of the correlation of associated variables between dimensions of human capital and innovation capital (expressed in the indicator of patents and utility models).

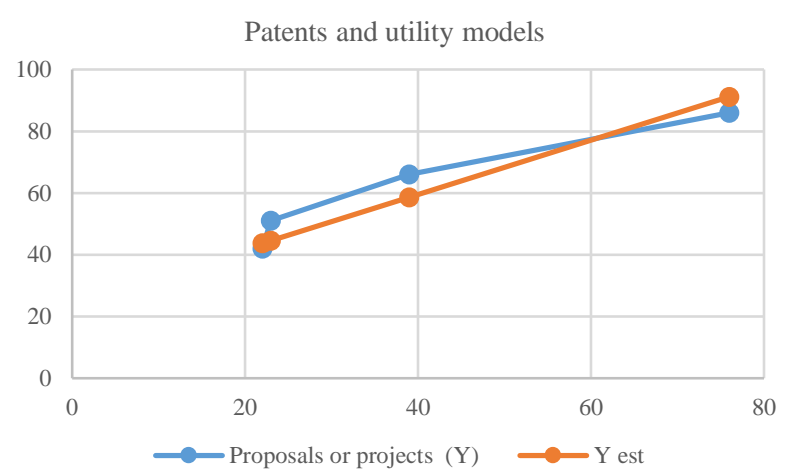

Graph 1 Linear correlation for the variables feeling of belonging, commitment and self-motivation

Source: Own Elaboration with database data (Díaz and Ordaz, 2019)

The next step is to obtain the coefficient of determination ( $\mathrm{r} 2$ ), by substituting its formula.

$r^{2}=\sqrt{ } \frac{\Sigma(Y e s t-Y m) 2}{\Sigma(Y-Y m) 2}$

Substituting the values we have that the result identifies that the fit to the model is very good, since the maximum value should be 1 .

$$
3123.30093 / 3432.83333=0.9098318
$$

With this last result, the percentage of unexplained information is obtained. 
Percentage of unexplained information 1 - $\mathrm{R}=(1-0.9098318)=0.0901682$, which is proof that the behavior is totally linear.

The next correlation that we sought to test were the variables associated with "Patents and utility models and communication (exchange and knowledge)", using linear regression. Socialization and customer orientation and self-motivation as shown in Table 5. The size of sample the was defined in the following statistic model:

$$
\mathrm{n}=\mathrm{p}^{*} \mathrm{q}(\mathrm{Z} / \mathrm{e})^{2}
$$

$$
\begin{aligned}
& \begin{array}{l}
\text { Donde } \\
\mathrm{n}=\text { Sample size } \\
\mathrm{p}=\text { Sucess } \\
\mathrm{q}=\text { Failure } \\
\mathrm{z}=\text { Area down the curve } \\
\mathrm{e}=\text { Allowed error }
\end{array}
\end{aligned}
$$
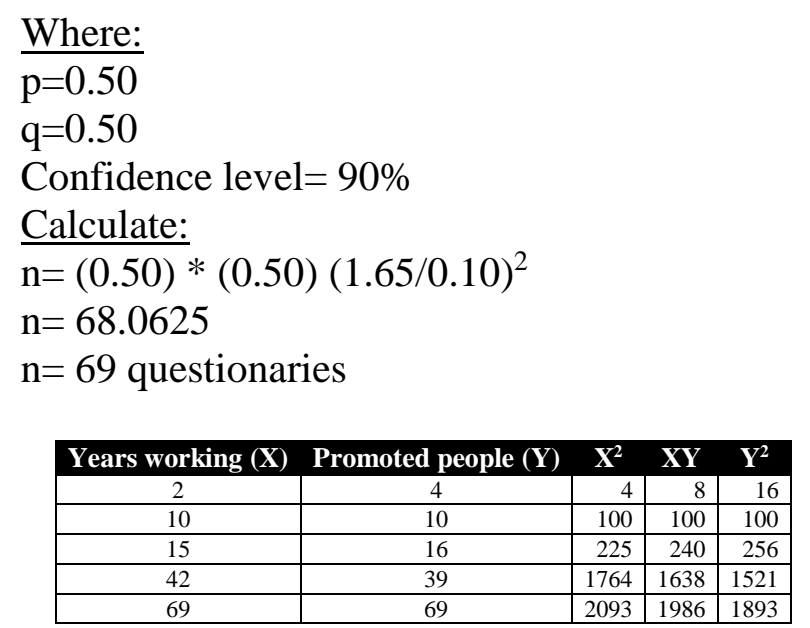

Table 5 Initial values. Socialization and customer orientation and self-motivation

Source: Own Elaboration based on Survey data (Díaz and Ordaz, 2020)

This allows to identify an improvement in the fit of the equation such as:

$y=2.04458599+.88147328 x$

Table 6 shows the results of the correlation of the variables that were considered in the initial survey of MSMEs in 2019.

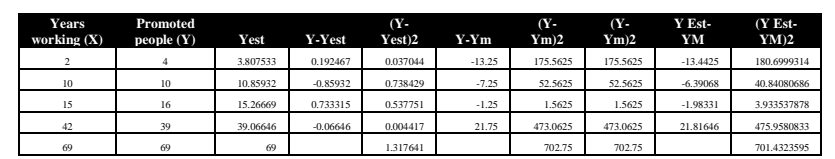

Table 6 Correlation results. Socialization and customer orientation and self-motivation

Source: Own Elaboration based on Survey (Díaz and Ordaz, 2020)

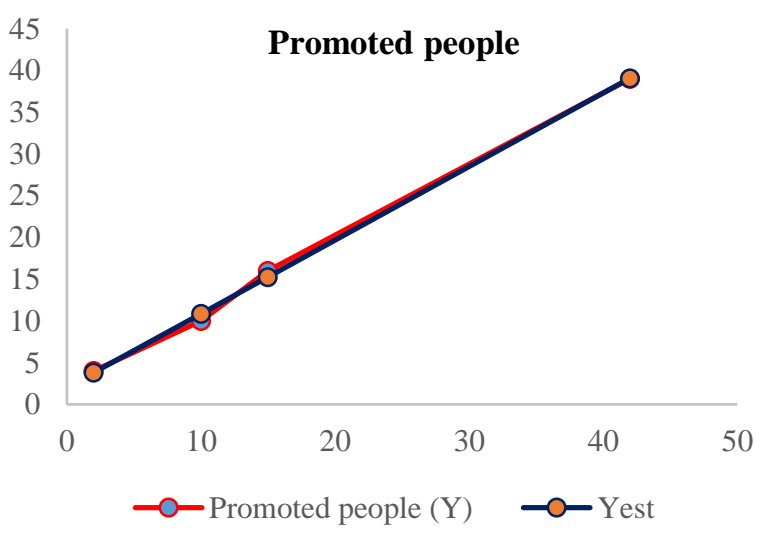

Graph 2 Linear correlation. Socialization and customer orientation and self-motivation

Source: Own Elaboration based on the 2019 Survey (Diaz and Ordaz, 2019)

Substituting the values in the equation:

$\frac{\sum(Y \text { Est }-Y M) 2}{\left(Y-Y_{M}\right)}$

You can see a completely linear fit.

$\frac{701.4323595}{702.75}=.998125$

$\mathrm{r}^{2}=\sqrt{.998124}$

$\mathrm{r}^{2}=.9990$

Therefore, it is considered that the fit is favorable, and the percentage of unexplained information is obtained. That is, the percentage of unexplained information $1-\mathrm{r}=$ (1$1.0018785)=-0.0018785$ with this result it is concluded that all the information was explained or received.

This result then allows us to respond to the proposed hypothesis in a positive way, that is:

It is possible to affirm that there is statistical evidence of the correlation of variables associated with motivation, training, sense of belonging, self-motivation and customer orientation (human capital) and the management of innovation capital in the MSMEs of Silao, León and San Francisco del Rincón that were surveyed in 2019.

Specifically, these companies are accepting project proposals from their employees, which is allowing them to have an impact on patenting, through some legal figure, thus enabling communication and knowledge exchange.

DÍAZ-GONZÁLEZ, Claudia, ORDAZ-PICÓN, Carla and GÓMEZNEGRETE, Guadalupe de Jesús. Survey and analysis of the indicators of intellectual capital in MiPymes of León, Guanajuato under the Intellectus Model approach. Journal-Business Administration-Marketing; Accounting. 2021 
On the other hand, this involvement of the personnel in strategic areas of the company makes it possible to have a permanence in the company, better working conditions when achieving promotions and consequently a better identification with it.

The value of the intangible assets of these companies must be calculated in the medium term from their participation in the market or from the growth of their innovation capital and their relational capital such as relationship with clients, suppliers, strategic alliances, among others.

\section{Conclusions}

The statistical analysis presented in this article confirms the theoretical assumptions that have been discussed throughout the papers around the management of intellectual capital and intangible assets as part of the new approaches to business management in the 21 st century.

The effects of the COVID 19 pandemic have significantly redefined the strategies of all economic agents worldwide and actions aimed at modifying personnel, fixed assets and financial management schemes have been accelerated.

Therefore, research on the operating conditions of companies at the local level should direct its attention to the use of human capital as a source of innovation around the use of technological capital.

The Intellectus Model arises from the evolution of schemes that seek to explain how intangible assets explain the behavior of productivity.

The proposed analysis of intellectual capital from the 3 dimensions (human capital, structural capital and relational capital) provides an important methodological value to carry out longitudinal studies on the evolution of these elements as part of the new business economic scenario.

This study generally establishes some important associations that may lead to a subsequent statistical validation based on the results of the surveys applied in 2019 by those responsible for the project.
Human capital indicators are strongly associated with the increase in structural and technological capital in companies that are older and show greater interest in the motivation and incentives of human capital. On the other hand, technological capital increases to the extent that educational levels also increase and this works as an accelerator of the use of intangible resources.

The possibilities of participating in processes to improve products and services are increased in environments in which there is a human capital with greater motivation and a feeling of belonging. The generation of knowledge then allows us to be at the center of the initiatives, aimed at having better structured businesses and participating in the new industrial ecosystems that are developing in the region.

Ultimately, this work starts from the premise that beyond industrial and technical approaches, the engine of socioeconomic development must be linked to the human being and their relationships, as a system for the creation and transfer of information and basic knowledge in the cumulative process that leads to innovation, well-being and quality of life. The use of talent and the set of organizational capacities are aimed at developing innovation and improvement tasks.

This will enable those companies called PYMES (Small and Medium Enterprises) or Microenterprises to have new elements of judgment or key aspects for their management. In this sense, they should consider the execution of continuous improvement plans in terms of quality, to identify or design their competitiveness strategies not only at the local level but also globally based on the use of intellectual capital derived from new approaches to human capital. In the short term, these strategies would tend to ensure the achievement of the mission and vision objectives that guarantee the competitiveness and future sustainability of the organization. Finally, the evidence obtained in the study and analysis of the behavior of the indicators confirms it is necessary to focus on professionalization strategies that allow people to train and grow within the organization; b) develop competency and performance measurement systems to achieve, through learning, the elimination of existing gaps, 
c) implement better recruitment and selection systems in order to choose the optimum personnel aligned with the culture of lifelong learning and willing to train ; d) create incentive systems, both monetary and nonmonetary, which encourage learning and knowledge transfer within and outside the company or organization.

Finally, the results of this exploratory research reach to a conclusion that it is necessary to continue observing the trend of the Intellectus Model indicators at the local and regional level in Mexico, since in the case of Guanajuato, there are important knowledge transfer chains that can trigger linkages and innovation among development agents at the micro level with a significant impact on the competitiveness of companies in the region. The need to have longitudinal studies through observatories of trends around intellectual capital are relevant if we consider that the strengthening of human capital will have therefore an increase in the capital of entrepreneurship and innovation.

Future work aims to continue monitoring the indicators in a greater number of companies and above all to observe how the indicators will behave in the post-COVID era that has accelerated the need for a change in the style and means of conventional management.

\section{References}

Bontis, N., \& Fitz-enz, J. (2002). 'Intellectual Capital ROI: A causal map of human capital antecedents and consequents", Journal of Intellectual Capital, 3, 223-247.

Bueno, E, \& Salmador, Ma. Paz, \& Merino, C. (2008). Génesis, concepto y desarrollo del capital intelectual en la economía del conocimiento: Una reflexión sobre el Modelo Intellectus y sus aplicaciones. Estudios de Economía Aplicada, 26 (2), 43-63 [Fecha de Consulta 6 de Enero de 2020. Disponible en: https://www.redalyc.org/articulo/301131870 03

Bueno, E. \& Murcia Rivera, C. \& Longo, Monica \& Merino, C. \& Real, Hermogenes \& Fernández, Pablo \& Salmador, Maripaz. (2011). Modelo Intellectus: Medición y Gestión del Capital Intelectual. https://www.researchgate.net/publication/29834 6530
Chaharbaghi, K., \& Cripps, S. (2006). 'Intellectual capital: direction, not blind faith", Journal of Intellectual Capital, 7, 29-42.

Díaz, C; Ordaz, P.; et. Al (2020). "Estudio y Análisis del comportamiento de indicadores de la gestión del capital intelectual en Mipymes de León, Guanajuato bajo el enfoque del Modelo Intellectus", Revista de Desarrollo Económico, vol. 7 , no. 22 p.p. $19-29$

Disponible

en: https://www.ecorfan.org/bolivia/researchjournal s/Desarrollo_Economico/vol7num22/Revista_d e_Desarrollo_Economico_V7_N22_3.pdf

Martín de Castro, G; Alama E; et. Al (2009) El capital relacional como fuente de innovación tecnológica INNOVAR. Revista de Ciencias Administrativas y Sociales, vol. 19, núm. 35, septiembre-diciembre, 2009, pp. 119-132 Disponible

en:https://www.redalyc.org/articulo.oa?id=818/ 81819026009rticulo.oa?id=818/81819026009

Edvinsson y Malone (1999). El capital intelectual. Como identificar y calcular el valor de los recursos intangibles de su empresa. Gestión, 2000.

Gentzoglanis, Anastassios (2000). Innovation and Growth in the Knowledge-based Economy. Ciencia Ergo Sum, vol. 7, no. 3, noviembre, UAEM. Disponible en http://www.redalyc.org/articulo.oa? $\mathrm{id}=1040190$ 2

Keklik, M. (2018) Schumpeter, Innovation and Growth, Long-Cycle Dynamics in the PostWWII American Manufacturing Industries, Routledge Revivals, 2a. ed., London and New York.

Fernández-Jordán, C.; Martos, S. Capital intelectual y ventajas competitivas en pymes basadas en recursos naturales de Latinoamérica, Innovar, Volumen 26, Número 60, p. 117-132, 2016 Disponible en: DOI: https://doi.org/10.15446/innovar.v26n60. 55548

Rózga Luter, R. (2003). Sistemas Regionales de Innovación: Antecedentes, Origen y Perspectivas. Convergencia. Revista de Ciencias Sociales, 10 (33). Disponible en: http://www.redalyc.org/comocitar.oa?id=10503 310 
OCDE. (1996). The knowledge-based economy.

Paris: OCDE

Fundación Este País (2005). México ante el reto de la Economía del Conocimiento, México Disponible

http://archivo.estepais.com/inicio/historicos/174 /20_suplemento_mexico\%20ante\%20el\%20reto .pdf

The World Bank. (2007). Building knowledge economies. Advanced strategies for development. Washington, D.C.: The World Bank.

Valdez Juárez, L. E., Pérez de Lema,D. G, Maldonado. (2017) TIC y la gestión del conocimiento como elementos determinantes del crecimiento de la PYME. Investigación y Ciencia de la Universidad Autónoma de Aguascalientes. Número 70: 50-62, enero-abril 2017.

\section{Thanks}

To the Tecnológico Nacional de México campus León for providing the facilities to carry out this project.

To the students of the Business Management Engineering career at IT León who supported the application of these surveys in the first part of the project and the organization of the database to analyze the statistical calculations.

To the Department of Administrative Economic Sciences for the support and interest in the formation of a new academic body. 